Н. О. Дудченко, О. Б. Брик

Інститут геохімії, мінералогї та рудоутворення ім. М. П. Семененка НАН Украӥни

\title{
ТЕРМОМАГНИТНІ ДОСЛІДЖЕННЯ ВПЛИВУ ВУГІЛЛЯ ТА ОРГАНІЧНОГО ВУГЛЕЦЮ НА ПЕРЕТВОРЕННЯ СТРУКТУРИ ГЕМАТИТУ В МАГНЕТИТ
}

Термомагнітні дослідження перетворення гематиту на магнетит за впливу активованого вугілля та крохмалю були проведені за допомогою лабораторної установки, що дозволяє автоматичну ресстрацію намагніченості зразка в залежності від температури (нагрів та охолодження проводили зі швидкістю $65-80 \%$ хв). Показано, що відновлення гематиту крохмалем відбувасться за температур до $650^{\circ} \mathrm{C}$ та призводить до отримання магнітного матеріалу з намагніченістю насичення $\sim 50 \mathrm{~A}^{*} \mathrm{M}^{2} /$ кг. Відновлення гематиту вугіллям в такому ж температурному діапазоні призводить до отримання продукту з намагніченістю $\sim 0,5 \mathrm{~A}^{*} \mathrm{M}^{2} / \kappa г$.

Ключові слова: гематит, магнетит, фазові перетворення, термомагнітні дослідження.

Термомагнитные исследования превращения гематита в магнетит при влиянии активированного угля и крахмала были проведены с помощью лабораторной установки, которая позволяет автоматическую регистрацию намагниченности образца в зависимости от температуры (нагрев и охлаждение проводили со скоростью 65-80\%/мин). Показано, что восстановление гематита крахмалом происходит при температуре до $650^{\circ} \mathrm{C}$ и приводит к получению магнитного материала с намагниченностью насыщения $\sim 50$ A* ${ }^{2} / \kappa г$. Восстановление гематита углем в таком же температурном диапазоне приводит к получению продукта с намагниченностью $\sim 0,5 \mathrm{~A}^{*} \mathrm{M}^{2} / \mathrm{\kappa}$.

Ключевые слова: гематит, магнетит, фазовые превращения, термомагнитные исследования.

Thermomagnetic investigations of hematite into magnetite transformations by activated carbon and starch were carried-out using laboratory facility, that allows automatic registration of sample magnetization with the temperature (the rate of sample heating/cooling was $65-80 \% \mathrm{~min}$ ). It was shown, that reduction of hematite by starch occurs by the temperatures up to $650^{\circ} \mathrm{C}$ and leads to formation of magnetic material with saturation magnetization $\sim 50 \mathrm{~A}^{*} \mathrm{~m}^{2} / \mathrm{kg}$. Reduction of hematite by activated coal in the same temperature range leads to formation of the product with saturation magnetization $\sim 0,5$ A* $\mathbf{m}^{2} / \mathbf{k g}$.

Key words: hematite, magnetite, phase transformations, thermomagneic investigations.

Вступ. Сьогодні при сучасних технологіях збагачення залізних руд для виробництва залізорудних концентратів високодисперсні окислені залізні руди мало використовуються. Такі типи руд складуються $\mathrm{i}$, таким чином, займають велику площу продуктивних земель, а також негативно впливають на навколишне середовище. Тому розробка і впровадження нових енергетично ефективних методів збагачення таких типів залізних руд може істотно підвищити рентабельність використання окислених залізних руд при створенні залізорудних концентратів, а також вирішувати екологічні проблеми залізорудних регіонів.

3 античних часів при виробництві заліза із залізної руди як паливо використовували вугілля або деревне вугілля, що містить вуглець, для того, щоб генерувати тепло і відновлювальні гази, що необхідні для відновлення руди [2]. Деревне вугілля використовувалось до середини 19 сторіччя, i, після цього, кокс, вироблений з вугілля, стає стандартним паливом для виплавки заліза. 
Постановка проблеми. Зараз відомо багато способів перетворення структури та магнітних характеристик оксидів та гідроксидів заліза. Наприклад, спосіб [3] перетворення структури оксидів заліза за випал-магнітною технологією, який заснований на використанні відновників, а саме суміші монооксиду вуглецю та водню та значних температур $\left(900-1450^{\circ} \mathrm{C}\right)$. Відомий спосіб [4], що включає змішування вихідного оксиду заліза 3 дисперсним вуглецем (співвідношення оксиду до вуглецю складало 6-7:1) та відпал за температури $600-700{ }^{\circ} \mathrm{C}$ протягом 30-60 хв.

В результаті використання всіх наведених вище способів 3 немагнітних окислених залізних руд отримують магнітну сировину, яку потім використовують для отримання залізовмісного концентрату за допомогою методу магнітної сепарації. Проте, всі ці способи потребують значних енергетичних затрат.

Раніше нами був запропонований новий спосіб [5] перетворення слабомагнітних оксидів/гідроксидів заліза, бідних окислених залізних руд та залізорудних відходів, що полягає в тому, що подрібнену сировину змішують 3 природними вуглеводами в сухому або розчиненому вигляді, нагрівають до температури $300-600^{\circ} \mathrm{C}$ та витримують до досягнення постійної намагніченості (10-30 хв. в залежності від температури та мінералогічного складу джерела гідроксидів заліза).

Метою даної роботи було отримання термомагнітних кривих перетворення гематиту в магнітний продукт 3 використанням в якості відновника активованого вугілля ZL-302 (Китай) та порівняння його 3 крохмалем, що запропонований в розробленому нами способі [5].

Зразки та методи їх дослідження. Зразок багатої залізно-слюдко-мартитової руди 3 вмістом заліза $62,5 \% \mathrm{Fe}$, подрібнену до розмірів 0,07-0 мм. В якості відновників для фазового перетворення гематиту в магнетит використовували джерело органічного вуглецю (крохмаль 3 вмістом вуглецю близько 50\%) та активоване вугілля (ZL-302, вміст вуглецю 100\%).

Для дослідження характеристик зразків до їх омагнічення 3 крохмалем та активованим вугіллям використовували методи рентгено-фазового аналізу, магнітометрії та ефекту Мессбауера (ядерний гама-резонанс) на ядрах ${ }^{57} \mathrm{Fe}$. Для дослідження магнітних характеристик зразків після омагнічення використовували метод магнітометрії.

Діагностика фаз з використанням рентгено-фазового аналізу проведена у відповідності з [1] за міжплощинними відстанями, визначеними за рефлексами дифрактограм.

Визначення намагніченості насичення проведено на магнітометрі 3 датчиком Хола в діапазоні від -0,45 мТл до 0,45 мТл. Калібровка приладу для вимірів намагніченості проводилась за еталонним зразком 3 відомим значенням намагніченості насичення (зразок чистого нікелю, намагніченість насичення якого за кімнатної температури становила $\left.54,4 \mathrm{~A} \cdot \mathrm{m}^{2} / \kappa г\right)$.

Мессбауерівські спектри (МС) отримані на установці постійних прискорень 3 використанням джерела ${ }^{57}$ Со в матриці хрому при кімнатній температурі експозиції зразків. Обробка MC виконана по програмі Univem2, що реалізує метод найменших квадратів. Інтенсивності ліній поглинання в секстетах магнітного розщеплення попарно 1-6, 2-5 і 3-4, а напівширини всіх шести ліній прирівнювались. В дублетах квадрипольного розщеплення прирівнювались як інтенсивності, так і напівширини обох ліній поглинання. Ізомерні зсуви наведені відносно $\alpha$-Fe. 
Термомагнітні дослідження виконувалися за допомогою установки для термомагнітних досліджень, яка дозволяє автоматичну реєстрацію намагніченості зразка в залежності від температури. Нагрів та охолодження проводили зі швидкістю $65-80 \%$ хв.

Експериментальні результати та їх обговорення. За даними рентгенофазового аналізу вихідний зразок складався 3 гематиту та слідів кварцу (рентгенограма вихідного зразка наведена на рис. 1).

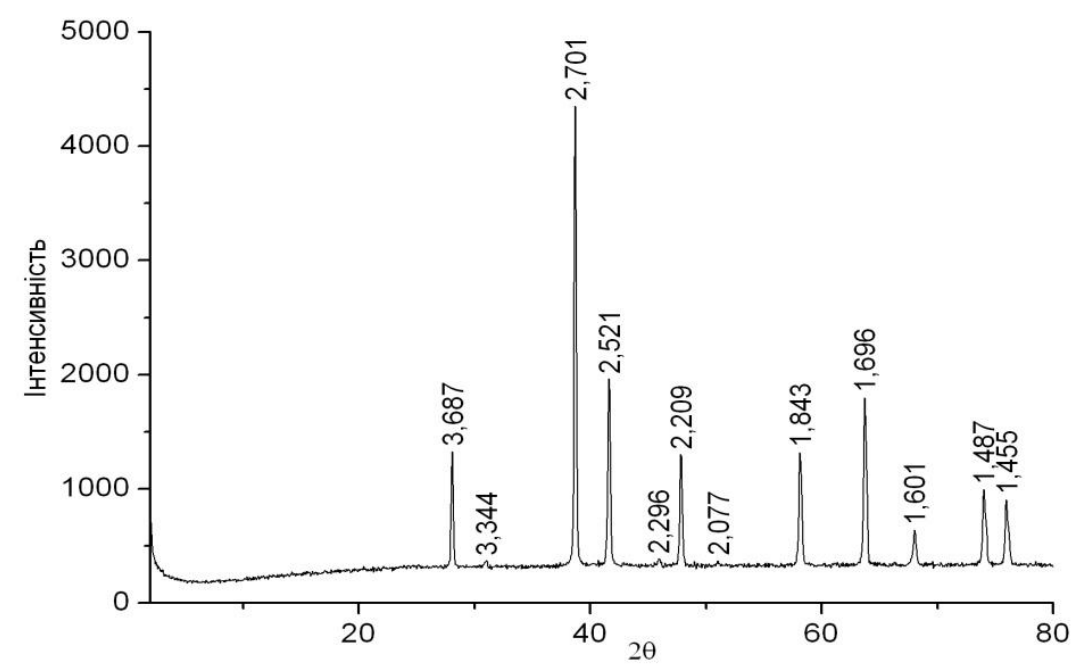

Рис. 1. Рентгенограма вихідного зразка

Мессбауерівський спектр вихідного зразка наведений на рис. 2.

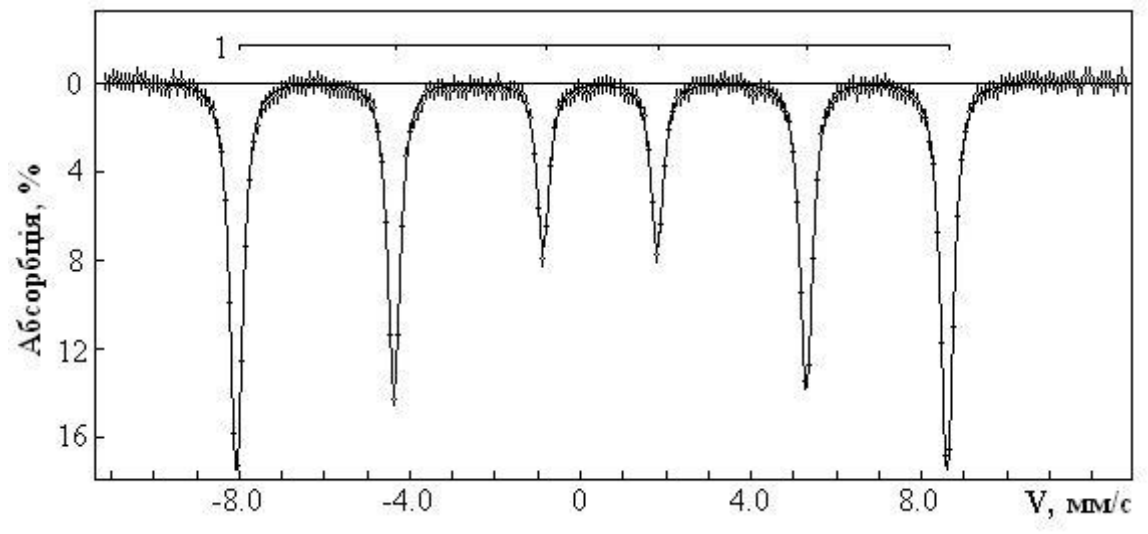

Рис. 2. Мессбауерівський спектр вихідного зразка

Месбауерівський спектр представлений одним секстетом магнітного розщеплення, який на порівняльній основі його параметрів 3 літературними даними [6] віднесений нами до резонансного поглинанням гамма-квантів на ядрах $\mathrm{Fe}^{3+}$ в структурі гематиту $\left(\alpha-\mathrm{Fe}_{2} \mathrm{O}_{3}\right)$. Намагніченість насичення вихідного зразка складала $\mathrm{M}_{\mathrm{s}}<1 \mathrm{~A}^{*} \mathrm{M}^{2} / \mathrm{\kappa}$.

Вихідний зразок перемішували окремо 3 2\% активованого вугілля та $4 \%$ крохмалю, які використовували в подальшому для термомагнітних досліджень. 
Для проведення термомагнітних досліджень наважку зразка 3 активованим вугіллям масою 0,6 г вміщували в кварцевий міні-реактор та здійснювали нагрівохолодження до температури $650^{\circ} \mathrm{C}$ зі швидкістю $65^{\circ}$ хв. Термомагнітна крива наведена на рис. 3 .

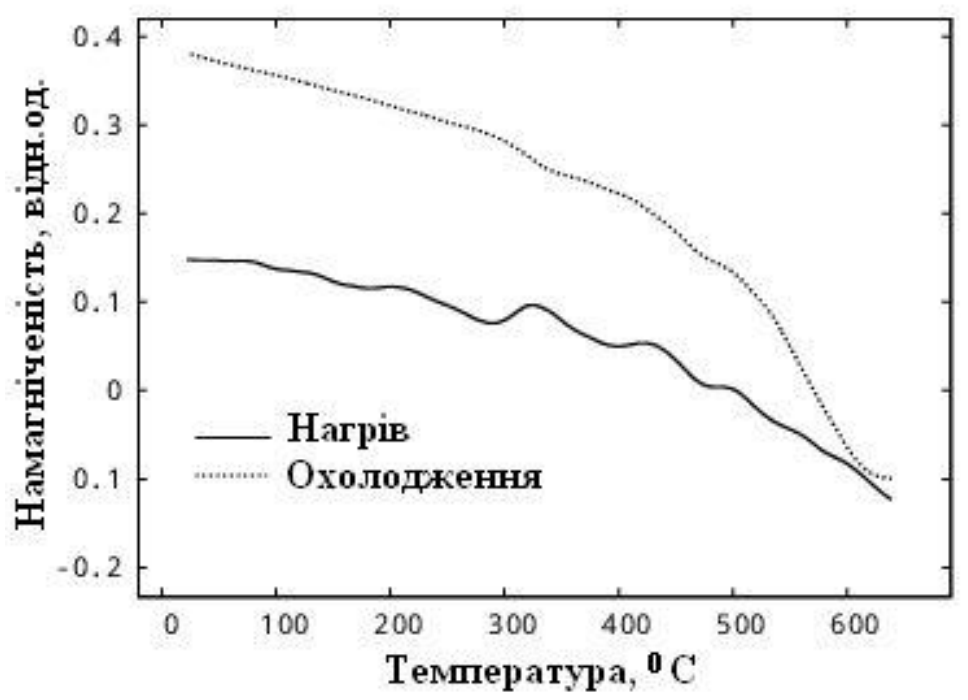

Рис. 3. Термомагнітна крива гематитвмісного зразка 3 активованим вугіллям

Показано, що після нагріву гематитової руди 3 активованим вугіллям до температури $650^{\circ} \mathrm{C}$ при охолодженні спостерігається незначне підвищення намагніченості зразка.

Той самий зразок було прогріто послідовно ще 2 рази до температури $650^{\circ} \mathrm{C}$ (рис. 4, 5). При такому прогріві підвищення намагніченості зразка не спостерігалося, i, навпаки, спостерігалося деяке зменшення намагніченості.

Намагніченість зразка після трьох циклів складала $0,48 \mathrm{~A}^{*} \mathrm{~m}^{2} / \kappa г$.

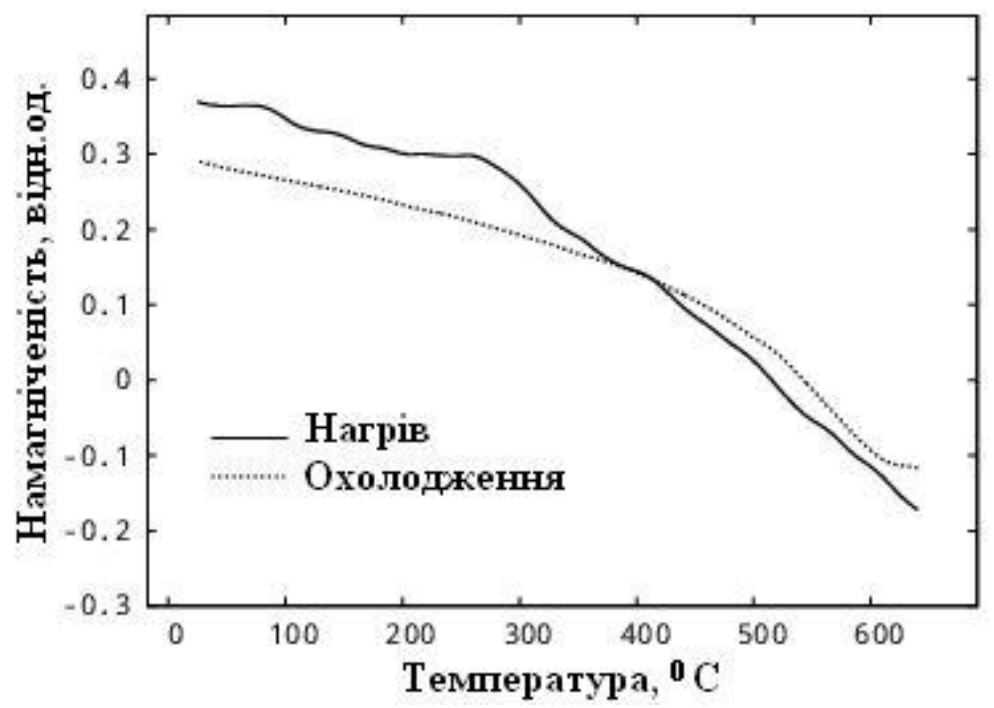

Рис. 4. Термомагнітна крива гематитвмісного зразка з активованим вугіллям (другий цикл) 


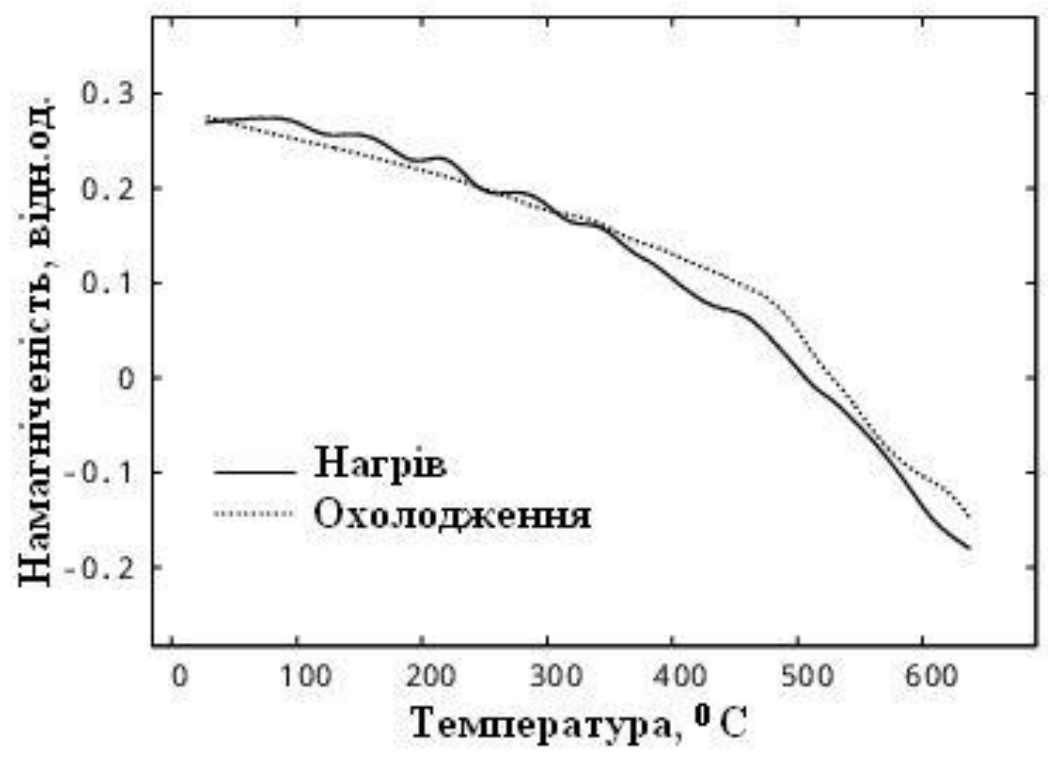

Рис. 5. Термомагнітна крива гематитвмісного зразка з активованим вугіллям (третій цикл)

Після цього було зареєстровано термомагнітну криву при нагріві зразка до температури $800^{\circ} \mathrm{C}$ зі швидкістю $80^{\circ}$ хв (рис. 6,7 ).

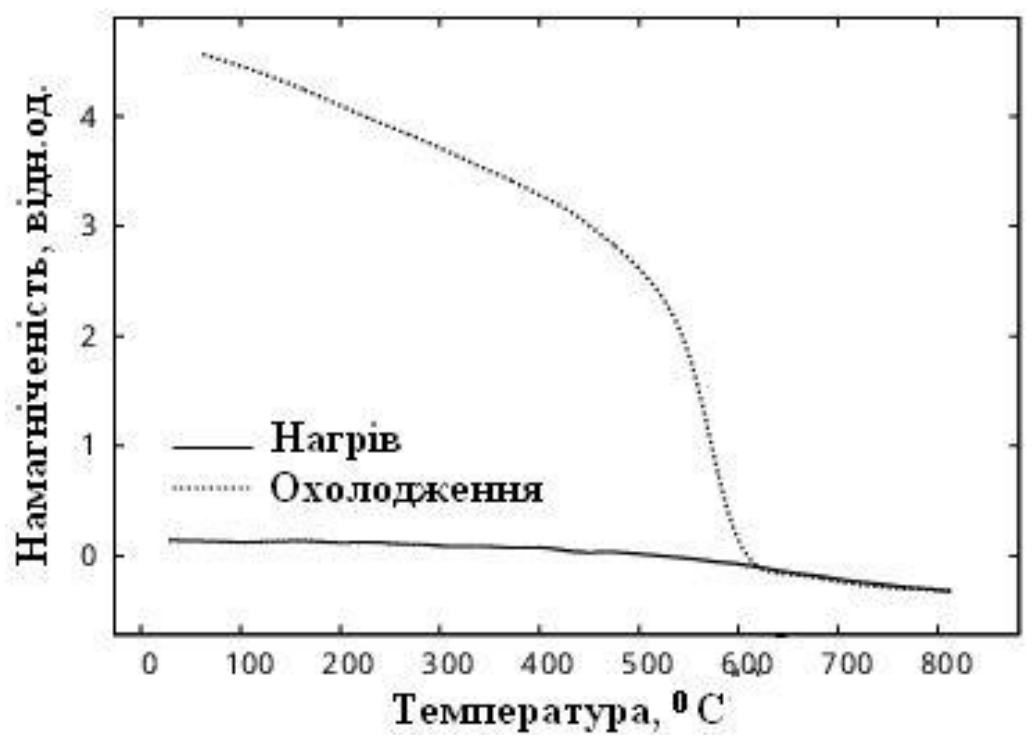

Рис. 6. Термомагнітна крива гематитвмісного зразка з активованим вугіллям до температури $800^{\circ} \mathrm{C}$ (перший цикл) 


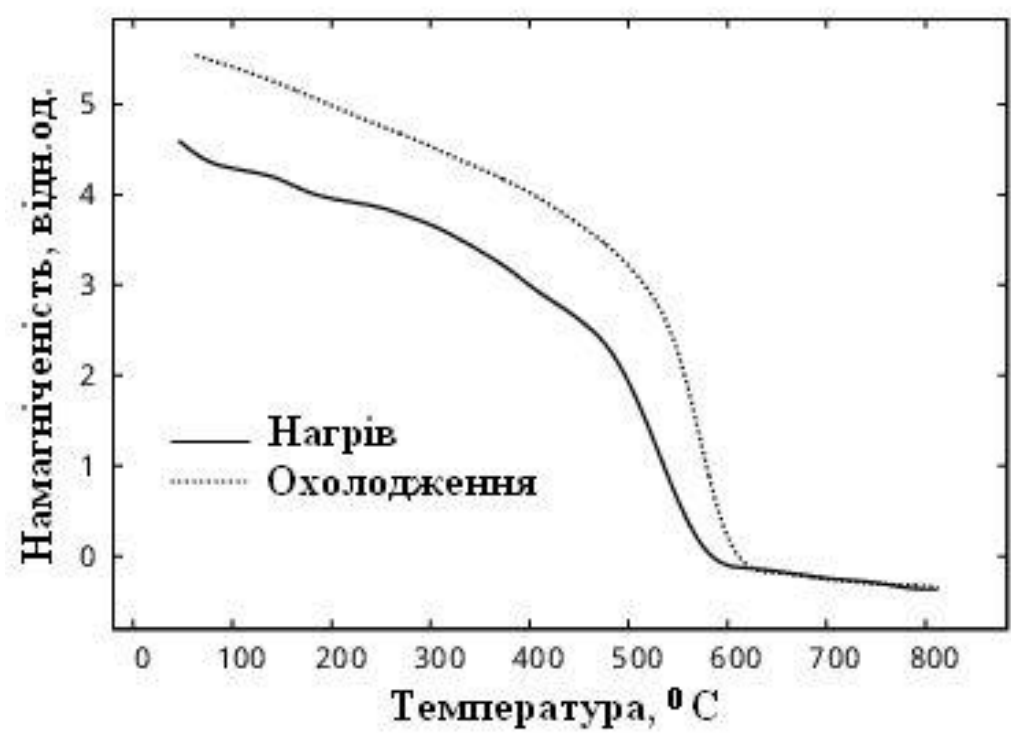

Рис. 7. Термомагнітна крива гематитвмісного зразка з активованим вугіллям до температури $\mathbf{8 0 0}^{\circ} \mathrm{C}$ (другий цикл)

Показано, що після охолодження намагніченість підвищується. Намагніченість зразка після двох циклів складає 10,3 $\mathrm{A} *_{\mathrm{m}}^{2} /$ кг.

Для проведення термомагнітних досліджень зразка гематитової руди 3 крохмалем, наважку зразка масою 0,3 г вміщували в кварцовий реактор та здійснювали нагрів-охолодження до температури $650^{\circ} \mathrm{C}$ зі швидкістю $65^{\circ} /$ хв. Термомагнітна крива наведена на рис. 8.

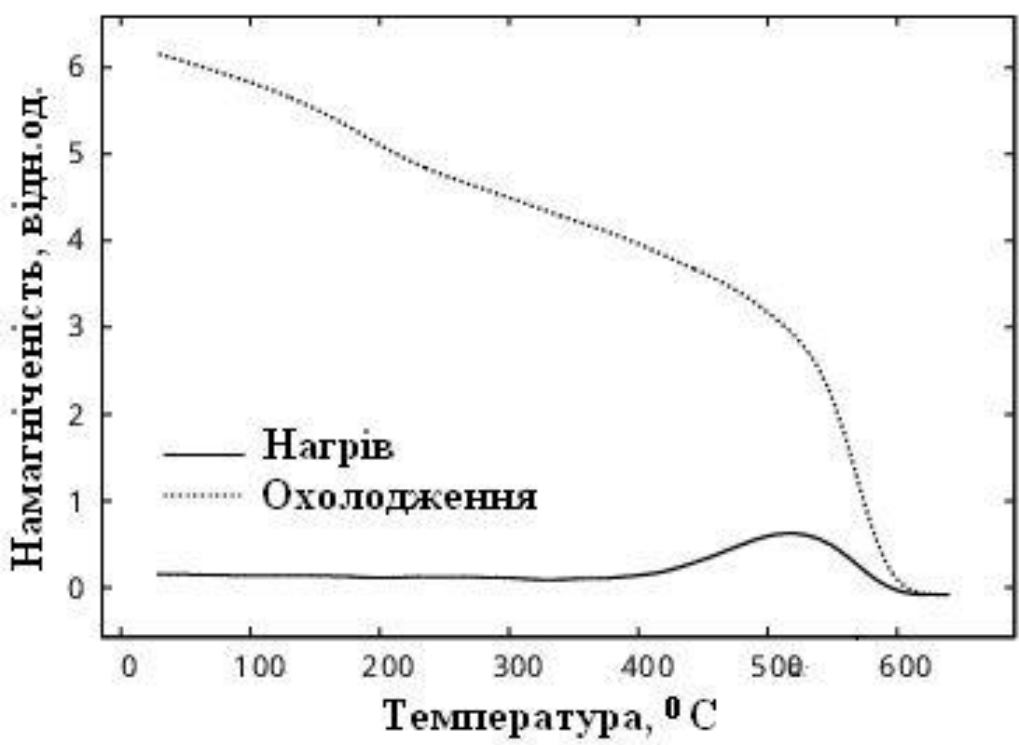

Рис. 8. Термомагнітна крива гематитвмісного зразка 3 крохмалем

В порівнянні 3 отриманими результатами, проведення термомагнітних досліджень для зразка гематитової руди 3 крохмалем показали, що на термомагнітній кривій нагрівання початок реакції спостерігається за температури 
$400^{\circ} \mathrm{C}$ з максимумом за температури $500^{\circ} \mathrm{C}$. На кривій охолодження намагніченість значно зростає. Показано, що температура Кюрі, визначена по кривій охолодження, складає близько $580^{\circ} \mathrm{C}$, отже, можемо зробити висновок, що в результаті реакції утворюється фаза магнетиту. Намагніченість насичення цієї руди після інкубації 3 крохмалем складає $51 \mathrm{~A}^{*} \mathrm{M}^{2} /$ кг (рис. 9).

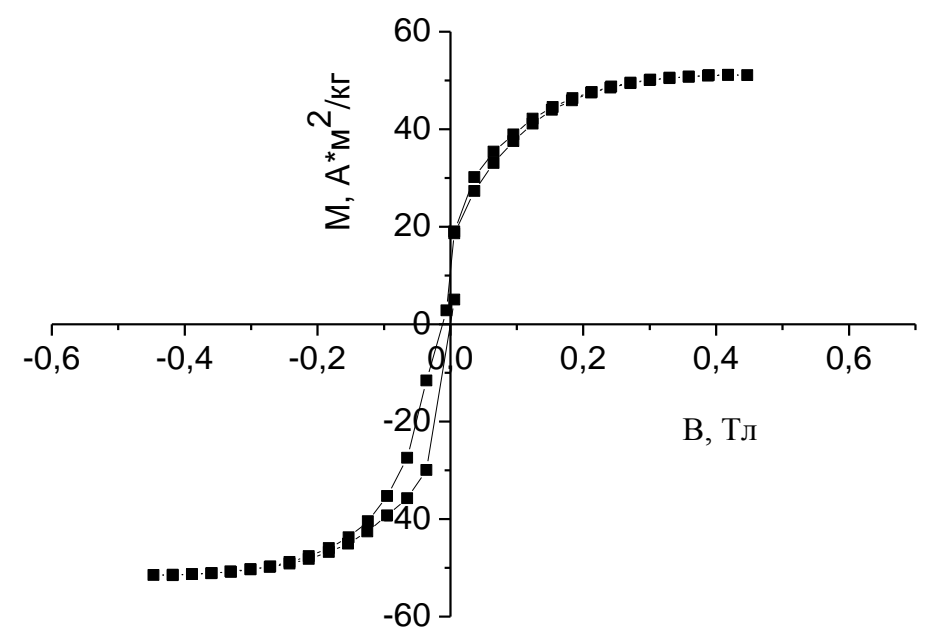

Рис. 9. Крива намагніченості омагніченого зразка гематитової руди

Висновки. Показано, що відновлення гематиту до магнетиту за допомогою вугілля ZL-302 відбувається за значно вищих температур в порівнянні $з$ крохмалем. Відновлення гематиту крохмалем в температурному діапазоні $400^{\circ}-650^{\circ} \mathrm{C}$ призводить до отримання продукту з намагніченістю $\sim 50 \mathrm{~A}^{*} \mathrm{~m}^{2} /$ кг. Відновлення гематиту вугіллям в такому ж температурному діапазоні призводить до отримання продукту з намагніченістю $\sim 0,5 \mathrm{~A}^{*} \mathrm{M}^{2} / \kappa г$, а при нагріванні до $800^{\circ} \mathrm{C}$ намагніченість підвищується до $\sim 10 \mathrm{~A}^{*} \mathrm{~m}^{2} / \kappa г$. Таким чином, відновлення гематитових руд крохмалем є менш енергозатратним, що може бути використано при розробці нових способів отримання залізорудних концентратів.

Автори висловлюють подяку провідному науковому співробітнику відділу фізики мінеральних структур та біомінералогії Інституту геохімії, мінералогї та рудоутворення ім. М. П. Семененка с.н.с. Іваницькому В. П. за реєстрацію та інтерпретацію ЯГР-спектрів.

\section{Бібліографічні посилання}

1. ASTM. Diffraction data cards and alphabetical and grouped numerical index of X-ray diffraction data. - Philadelphia, 1946-1969.

2. Зверевич В. В. Основы обогащения полезных ископаемых /В. В. Зверевич, В. А. Перов. - М.: Недра, 1971. - 215 с.

3. Патент 3954444 США, МПК С21B 5/06 Process for the direct reduction of iron ores /W. Wenzel, P. Speih, F. H. Franke, B. Dreyer - Заяв. 15.02.1974; Опубл. 4.05.1976. 
4. Патент 28424 Україна, МПК G01G 49/08 Спосіб отримання магнетиту /В. Ю. Поліщук, Б. О. Дем'янчук, І. В. Поліщук. - Заяв. 06.02.1997; Опубл. 16.10.2000 // Бюл. № 5.

5. Патент 82527 Україна, МПК G01G 49/08 Спосіб омагнічування слабомагнітних окислених залізних руд і залізорудних відходів для магнітної сепарації з використанням відновлювальних джерел сировини /О. М. Пономаренко, О. Б. Брик, Н. О. Дудченко, В. В. Янишпольський, О. О. Юшин. - Заяв. 21.05.2013; Опубл. 12.08.2013 // Бюл. №15.

6. Пономаренко О. М. Властивості природних, синтетичних та біогенних оксидів і гідроксидів заліза за даними месбауерівської спектроскопії / О. М. Пономаренко, В. П. Іваницький, О. Б. Брик, Н. О. Дудченко. - К.: Наук. думка, 2013. - 159 с.

Надійшла до редколегії 02.04.2014 p. 